\title{
МРНТИ 16.21.45
}

\author{
Зайсанбаева Г.Н., ${ }^{1}$ Акимжанова Г.С. ${ }^{2}$ \\ ${ }^{1,2}$ «Тұран-Астана» университеті, \\ Нұр-Сұлтан, Қазақсттан
}

\section{ТУЫНДЫ СӨЗДЕРДІН СӨЗЖАСАМДЫК УӘЖДЕМЕСІ}

\section{Аңъдатпа}

Зерттеу жұмысының мақсаты - туынды сөздердің лексикалық мағынасын талдауда ғылыми маңызды сөзжасамдық уәждеме терминдерінің анықтамасын талдау. Аталымдағы сөзжасамдық уәждеме, туынды сөздердің жасалу үдерісіндегі тілден тыс факторларды көрсете отырып, сөздердің мағына негізділігі айқындалады.

Ғылыми зерттеудің жаңалығы қазақ тіліндегі аталым бірліктердің сөзжасамдық үдерісін талдау әдістемесі ұсынылады. Сөздердің ішкі мағыналық құрылымдарының зерделеуде, лингвистикалық талдаулар жүргізуде маңызды болып табылатын әдістер беріледі. Зерттеу нәтижесінде сөздердің ішкі мағыналық құрылымының түзілуіне әсер ететін жағдайлар сипатталып, сөздердің жасалуы мен әлемнің тілдік бейнесін қазақ халқын ерекшелейтін фактор ретіндегі байланысы зерделенеді.

Лексикалық бірліктердің жасалуын антропоөлшемділік тұрғысынан тануда, сөздің таңбалануы мен оның мағынасы арасындағы байланысын анықтай білу сөздің уәжділігі түсінігі арқылы беріледі. Сөздің уәжділігін анықтау барысында, бұл аталымға негіз болып тұрған мағына қандай, ол мағына қаншалықты өзгеріске түсті, яғни сөз мағынасының уәжділігі синхронды түрде қолданыста таныла ма деген сұрақтар төңірегінде ізденеміз.

Сөздердің уәжділігі мәселесін қарастыруда, ішкі мағыналық құрылым, уәждеме, уәждемелік белгі ұғымдарына кеңінен тоқталып, олардың тіл біліміндегі зерттелуіне байланысты сұрақтар талданады.

Түйін сөздер: аталым, уәждеме, уәждемелік белгі, сөзжасамдық мағына, сөздің ішкі құрылымы

$$
\begin{gathered}
\text { Zaysanbayeva } G .,{ }^{1} \text { Akimzhanova } G .{ }^{2} \\
{ }^{1,2} \text { Universit } « \text { Turan-Astana», } \\
\text { Nur-Sultan, Kazakhstan }
\end{gathered}
$$

\section{WORD FORMATION MOTIVATION OF DERIVED WORDS}

\begin{abstract}
The purpose of the research is to reveal the meaning of the terms of word-formation motivation as an important scientific component in the linguistic analysis of the study of the process of creating derivative words. The article identifies extralinguistic factors that contribute to determining the motivation of nominative units as the basis of the lexical meaning of words.

The scientific novelty of the research consists in the development of a methodology for analyzing the word-formation processes of nominative units in the Kazakh language. As a result, the conditions for the formation of the internal form of words are described, which show the connection between word formation and the creation of a language picture of the world, as a factor determining the linvocultural features of the Kazakh people.

The motivation of words determines the anthropocentricity of the formation of lexical units and is considered as the rationality of the relationship between the sound shell and the meaning of words. By studying the motivation of words, we can understand what meaning is the basis for this name, how much it has changed, that is, the motivation of the semantics of the word is analyzed synchronously.

Keywords: nomination, motivation, motivational sign, word-formation value, internal form of the word
\end{abstract}




\author{
Зайсанбаева Г.Н., ${ }^{1}$ Акимжанова Г.С. ${ }^{2}$ \\ ${ }^{1,2}$ Университет «Туран-Астана», \\ Нур-Султан, Қазахстан
}

\title{
СЛОВООБРАЗОВАТЕЛЬНАЯ МОТИВАЦИЯ ПРОИЗВОДНЫХ СЛОВ
}

\begin{abstract}
Аннотация
Цель исследования - расскрыть значение терминов словообразовательной мотивации, как важное научное составляющее в лингвистическом анализе изучения процесса создания производных слов. В статье выявленыэкстралингвистические факторы, способствущее определению мотивации
\end{abstract} номинативных единиц, как основа лексического значения слов.

Научная новизна исследованиязаключается в разработке методики анализасловообразовательных процессов номинативных единиц в казахском языке. В результате описаны условия образования внутренней формы слов, которые показывают связь словообразования и создания языкой картины мира, как фактор, определяющиейлинвокультурные особенности казахского народа.

Мотивированность слов определяет антропоцентричностьобразования лексических единиц и рассматривается, какрациональность связи между звуковой оболочкой и значением слов. Исследуя мотивированность слов, мы можем понять какое значение имеет быть основанием для этого названия, насколько оно изменилось, то есть мотивированностьсемантики слова анализируется синхронном аспекте.

Ключевые слова: номинация, мотивация, мотивационный признак, словообразовательное значение, внутренняя форма слова

Кіріспе. Кез келген атау - халықтың ғасырлар бойы жинақталған бай тәжірибесі мен білімінің нәтижесі, ойлау үдерісінің жемісі, сондықтан да заттар мен құбылыстарадам санасында олар жайында ұғымдар мен заттық белгілері туралы ақпараттар арқылы сақталады.

Зерттеу жұмысының мақсаты - туынды сөздердің лексикалық мағынасын талдауда ғылыми маңызды сөзжасамдық уәждеме терминдерінің анықтамасын талдау жасау.

Уәждеме теориясында уәждемелік мағына ұғымы атаулардың уәжділігін тануда аса маңызды. Әлем тіл білімінде уәждемелік мағына сөзжасамдық мағынамен байланыстыра қарастырылады. Сөзжасамдық мағына лингвистикада И.С.Улуханов, В.В.Лопатин, Е.А.Земская, Е.С.Кубрякова т.б. ғалымдар еңбектерінде әр қырынан қарастырылады. Бұл мәселені зерттеуде екі бағыттың қолданылып жүргені байқалады. Семасиологиялық бағытты ұстанушылар туынды сөз бен сөз тудырушы түбір арасындағы семантикалық айырмашылықты салыстыра отырып сөзжасамдық мағынаны айқындауға болады дейді. Аталым үдерісінде атауға негіз боларбелгінің маңызы сол атауды құраушы таңбалық белгісін айқындайды. Ол туралы тілші-ғалымдар аталым белгісі және уәждемелік белгі терминдерінің аражігін ажыратып алуды алға тартады. Қазақ тіл білімінде Н.Уәлиұлы, Б.Қасым, А.Салқынбай т.б. ғалымдар сөзжасамдық уәждеме тақырыбына зерттеу еңбектерін арнаған.

Атаулардың астарында тіл қолданушы таңдар белгі жатады, ол сөздің лексикалық мағынасының негізін құрайды. Уәждемеде осы белгіні анықтай білу, сөздің уәжділігін растайды.

Бұл ретте аталым белгісі «Шынайы өмірдің заттары мен құбылыстарына атау беруде таңдалынар белгі - аталым белгісі болып танылмақ〉 [1,131]. Тілші-ғалымдардың пікірінше, уәждемелік белгі және аталым белгісі - метатілдік мәртебеге ие түсініктер. Аталым белгісі мен уәждемелік белгі тілдік бірліктердің семантикасын қарастыруда ономосиологиялық не болмаса уәждемелік тұрғыда сараптауға байланысты қолданылады.

Аталым белгісі - көп жағдайларда тілден тыс мәртебеге ие. Өйткені аталым белгісі лексемалардың тілден тыс құбылыстармен байланысын анықтайды.

О.И.Блинова «Уәждемелік белгі - атауға негіз болған денотат белгісі», - деп көрсетеді [2,131]. Аталым белгісі тілден тыс экстралингвистикалық белгілерді анықтауда қолданылса, уәждемелік белгі лексемалардың жасалуының уәждемесінқарастыруда айқындалады деген шешімге келеміз. Аталым белгісі мен уәждемелік белгінің айырмашылығы, бірінің тілден тыс мәртебесінде болса, екіншісінің тілдік мәртебесінің басымдылығында депойлаймыз. 
Әдістеме. Сөздердің жасалуын антропоөлшемділік тұрғысынан тануда, сөздің таңбалануы мен оның мағынасы арасындағы байланысын анықтай білу сөздің уәжділігі түсінігі арқылы беріледі. Туынды сөздердің уәжділігі айқын немесе жасырын болу мүмкін.Сөздің уәжділігін анықтау барысында, ең бастысы бұл аталымға негіз болып тұрған мағына қандай, ол мағына қаншалықты өзгеріске түсті, яғни сөз мағынасының уәжділігі синхронды түрде қолданыста таныла ма деген сұрақтар төңірегінде ізденеміз.

Мысалы, елтаңба деген сөзді алар болсақ, сөз уәжділігі, яғни мағына негізділігі айқын. Ал байрақ сөзіне келсек, тіл қолданушы таңба мен лексикалық мағына арасындағы байланысты бірден ажырата алмайды. Сондықтан, сөздің уәжділігі жасырын, бұл ретте бізге этимология көмекке келеді. Осы сөздің уәжділігі жайында профессор Ж.Манкеева былай деп көрсетеді: «Байрақ: байрақ (қыр.,тат., қар., қаз., ноғ., башқ.) Көрсетілген тілдердің бәрінде ортақ мағына ту. Осыған орай оны байла, бау, бадал, бәйге сөздерімен қатар қарастыруға оның тарихи-салыстырмалы жүйедегі архетиптік тұлғасы -ортақ түбірі ба(й) байла $\dot{\sim}$ ба(у) $\dot{\sim}$ ба (д) (бадал) -badrug//bairag (байрақ) -ту негіз болады» -деп, бұл сөздің қазіргі таңда қайта жаңғырғанын атап өтеді [3, 47]. Диахрондық сипаттама беру арқылы сөздің мағына негізділігі зерделенді, бірақ қазіргі қолданыста атаудың мағына негізділігі бірден айқындала қоймайтындықтан оны жасырын уәжді сөздер қатарына жатқызамыз.

Уәждеме үдерісін түсінуде аталым теориясының ұстанымдарын басшылыққа аламыз. Жаңа нысандарды тануда адам бұрын жинақтаған білім қорын тиімді қолданады. Тілде өнертапқыштық элементтері болмайды деуге болады, атаулар санада бар түсінікке негізделіп туындайды. Жаңа құбылысты немесе қатынасты атау үшін өзгертілген, жаңарған ескі тілдік материал пайдаланылады жәнетілдегі қолданыстағы таңбаларды жаңарту (репрезентация) құбылыс үнемі жүріп отырады.

«Адам баласы өзіне таныс зат пен құбылысты одан әрі тереңдей білу арқылы, олардың белгісі мен қасиетін, қабілеті мен сапасын айқындап, әртүрліпайымдауларжасайды. Ал бұрын бейтаныс ұғымы мен таңбасы жаңа затты не құбылысты көргенде, мұндағы ұғым бұрынғы бар танымдық хабармен ұқсатылып,салыстырылып байланыстырылады.Бұл аналогиялық сөзжасамның көрінісі деуге болады. Адам жаңадан таныла бастаған заттар мен құбылыстарды бұрынғы түсінігі арқылы саралап, жаңа қасиеттерін айқындап, ерекше пайымдаулар жасайды», - деген ғылыми пікір жаңа нысандарды атаудағы адамның бай тәжірибелік білім қоры арқылы қайта жаңғыру заңдылықтары суреттеледі[4, 11].

Жаңа атаудың жасалуындағы шынайы болмыс нысандары туралы білім қорының тілдік деректерге айналуы жөнінде Б.Қасым: «Зат пен құбылысқа ат қоюда өмір шындығы, болмыс - тіл деректеріне, атауға айналады. Күрделі жасалымда жаңа мағына мен жаңа мазмұн пайда болған уақытта сол кезеңде барып жаңа сөз қалыптасады», - деген ойтүйіндеуін жасайды [5,11].

Сөзжасамда атаулар белгілі бір үлгі арқылы, сөзжасамдық форманттардың қатысымен жасалады. Тілде бұл үлгілерді сөзжасамдық формулалар деп тануымызға да болады. Бұл үлгілердің нәтижесінде сөзжасамдық мағыналар түзіледі.

Е.А. Земская «Словообразовательное значения устанавливается на основании семантического соотнесения ряда базовых и производных слов, характеризуемые общностью семантики и вычленяющих один и тот же словообразовательной формант» [6, 28]. Бір сөзжасамдық формантпен жасалынған туынды сөздердің негізгі сөзбен мағыналарының байланысының айырмашылығынан сөзжасамдық мағынаны анықтау,аффикстік жолмен жасалған туынды сөздердің сөзжасамдық мағынасын ашуда қолдануға болады.

И.С.Улухановтың «Сөзжасамдық форманттың берер мағынасы сөзжасамдық мағына болады», деген пікірі туынды сөздердің сөзжасамдық мағынасын айқындап береді[7].Сондықтан сөзжасамдық талдауларда сөзжасамдық мағына ұғымының маңызы зор.

Талдау. Сөзжасамдық мағына - әр топтағы сөздердің мағыналарының ассоциациялы байланысын бейнелеуші кешенді мағына. Мысалы: желбас (желікпе адам), қаңғыбас сияқты атауларда «белгілі бір мінез иесі» және «белгілі бір мінез сипаты» сияқты мағыналартоғысқан.

Сөзжасамдық мағына - сөзжасамға қатынасқан сыңарлардың мағынасы арқылы жасалатын туынды (дериваттық) мағына және сөзжасамдық мағына сөзжасамдық үлгі арқылы жүзеге асырылады.

Әр сөзжасамдық үлгі біздің түсінігімізше, оны құраушы сыңарларының қызметі мен өзара мағыналық байланысына қарай белгілі бір мағыналық формула арқылы берілуі қажет. Мысалы: зат есім + жай = атау үлгісінің мағыналықформуласы «қоғамның белгілі бір кең көлемді қажеттілігін 
қамтамасыз ететін арнайы орын». Бұл мағына осы үлгі бойынша жасалған шипажсай, әуежай, ж⿻аважсай сияқты атаулардың мағыналарына ортақ болады.

Туынды сөздің сөзжасамдық мағынасы мен лексикалық мағынасының аражігінде уәждемелік мағына анықталады. Күрделіатаулардың уәждемелік мағынасы оларды құраушы сыңарлардың мағынасының негізінде жасалғандықтан, метафоралы туындаған күрделі сөздердің метафоралы мағынасы бар деп ойлаймыз. «Мотивационное значение - значение или синтез значения мотивационной формы слова», - деген пікірден уәждемелік мағына, ал метафораларда метафоралық мағына оны жасаушы сыңарлардың ауыспалы мағыналарынан құралады деген шешімге жетелейдіУәждемелік мағына шартты түрде бейнеленеді. Уәждемелік мағынаның өзге мағыналардан айырмашылығын төмендегідей кескіндеуге болады:

\section{айдала}

заттың атауы, біріккен сөз - грамматикалық мағына

өзге нысан қасиетіне ұқсас мекен атауы - сөзжасамдық мағына

«айдай» дала - уәждемелік мағына

елсіз, жазық, мекиен дала - лексикалық мағына

Сөздің грамматикалық мағынасы оның дыбыстық тұрпатымен байланысты болса, сөзжасамдық мағына жалпылауыш және де сыртқы факторлармен байланысты, ал уәждемелік мағынаны ішкі мағыналық құрылымның суреттемесі деуге болады. Сөздің уәждемелік формасы және уәждемелік мағынасы оның ішкі мағыналық құрылымына енетін бөлшектері. О.И.Блинова бұл жайында уәждемелік форма ішкі мағыналық құрылымның дыбыстық жамылғышын қалыптастырса, уәждемелік мағына лексикалық мағынаның түзілуін бейнелейді деген тұжырымға келеді $[2,51]$.

Нәтижелер.Зерттеу нәтижесінде қазақ тілінің сөзжасам жүйесінде туынды сөздердің басым бөлігі уәжді сөз екеніне көз жеткіземіз. Сөздердің лексикалық мағынасын түсіндіруде олардың ішкі мағыналық құрылымына талдау жасай отырып, тілдегі мағына негізділігіне, яғни сөздердің уәжділігі ұғымына келеміз. Аталымда тіл қолданушының когнитивтік үдерісі сыртқы әлемнің зат, құбылыстарын зерттей отырып, оларға таңба беруде жадыда сақталған ақпарат қорларын белсендіріп, танымдық опрерациялар жасай отырып, атауларды ұсынады. Сондықтан да, тілдегі атаулар мағынасы уәжділігі ұғымы сөзжасамның басты түсінігі екендігін, сөзжасамдық талдауларда уәждемелік белгі, мағына, сөзжасамдық формант терминдерінің тілдік заңдылықтарды анықтауда назардан тыс қалмау керек деген тұжырым жасаймыз.

Аталымдардың жасалуын гнесеологиялық, лингвистикалық тұрғыда қалай саралау керектігі жөніндегі Б.Қасым:«Күрделі атау - дара сөз секілді қатысым және атаулық тілдік қызмет атқарумен қатар, бірінші кезекте, тілдік аталым құралы, тілде туынды лексема ретінде қалыптасқан сөздер. Сонымен күрделі атаулар - гнесеологиялық және лингвистикалық ұғымдардың жиынтығынан: зат ұғым - таным - мазмұн - мағына - белгі - таңба т.б. тоғыса байланып, бір- бірімен сөзжасамдық заңдылықтарға сүйене отырып түзілетін күрделі лексикалық бірліктер», -деген пікіріне сүйене отырып, тілдегі когнитивтік үдерістерді саралауда әр туынды сөздің мағыналық құрылымына да талдау жасала отырып, ортақ заңдылықтарға қол жеткіземіз[2,10].

Қолданыстағы аталымдардың қалыптасуы сөзжасамдық және танымдық үдерістер мен заңдылықтарға байланысты жүзеге асады. Аталымдардың жасалуындағы мағыналық даму, олардың өзара сәйкестігі сөздердің уәждемесін қарастырумен анықталады. Сөзжасамдағы ішкі мағыналық құрылымның өз ішінде дамып, өзгеруі адамның танымының дамуымен де астасыпжатады.

Күрделі атаулардың қалыптасуына сөзжасамдық тәсіл менқұралдар қатысып, аталымға қызмет етеді және қолданылу өрісінің кеңеюіне мүмкіндік береді. Күрделі аталымның жаңа сапалы мағынаның пайда болуына сыңарлардағы уәждеуші мағыналардың түрлі өзгерістерге түсуі, ол тілдің ішкі даму заңдылығына сай қалыптасып, содан жаңа мағыналы атау туындайды, тілдің лексикалық қоры дамиды .

Қорытынды. Сөздердің уәждемелік процесіне қатысатын ұғымдардың анықтамаларына тоқталған шолуымызды қорытындылай келе оларды былайынша жүйелейміз:

Уәждеме - заттың атауында танымдық және категориялық белгінің таңдалым және бекілім процесі.

Уәждеме процесі нәтижесінде таңдалынған және бекілген танымдық белгіні сөздің уәждемелік белгісі деп түсінеміз.

Сөздің уәжділігі - олардың жасалуын антропоөлшемділік тұрғысынан тануда, таңбалануы мен мағынасы арасындағы байланысты сипаттайтын лексикалық белгі. 
Сөздің ішкі мағыналық құрылымы - лексеманың морфемалық құрылымынан байқалатын тіл қолданушының санасында қалыптасқан денотаттың белгілерін елестету арқылы туындайтын бейненің көрінісі. Ішкі мағыналық құрылымда метафоралануға ұйытқы болып тұрған бейненің түзілу жолысуреттеледі.

Сөздердің ішкі мағыналық құрылымы, уәждеме, уәждемелік белгі, сөзжасамдық мағына терминдері лексикалық бірліктерге тілдік талдау жасауда маңызды және атаулар табиғаты мен тіл қолданушының дүниетанымының байланысын дәлелдейді.

Пайдаланылван ддебиеттер тізімі:

1 Кияк Т.Р. Мотивированность лексических единии. - Львов, 1988. - 160с.

2 Блинова О.И. Мотивология и ее аспекты.-2-е издание. -Томск: Из-во Том.ун-та, 2007. -394 с.

3 Манкеева Ж.А.Қазақ тіліндегі этномддени атаулардың танымдық негіздері, Алматы: «Жібек жоль»» баспа үйі, 2008.-356 б.

4 Салқынбай А.Б. Тарихи сөзжасам. Семантикалық аспект: Филол. выл. док. дисс. - Алматы, 1999. - 2846 .

5 Қасым Б.Қ. Қазақ тіліндегі заттың күрделі атауларының теориялық негіздері: Филол. выл. док. дисс. - Алматы, 2002. - 313 б.

6 Земская Е.А. Современный русский язык: Словообразование. - М: Просвещение, 1983. - 304c.

7 Улуханов И.С. О степенях словообразовательной мотивированности слов //ВЯ,. 1992, №5. - c. 107-110.

References:

1 Kiak T.R. Motivirovannöst leksicheskih edinis. - Lvov, 1988. - 160s.

2 Blinova O.I. Motivologia i ee aspekty.-2-e izdanie. -Tomsk: $\dot{I} z-v o$ Tom.un-ta, 2007. -394 s.

3 Mankeeva J.A.Qazaq tılındegı etnomädeni ataulardyñ tanymdyq negizderl, Almaty: «Jlbek joly» baspa üil, 2008.-356 b.

4 Salqynbai A.B. Tarihi sözjasam. Semantikalyq aspekt: Filol. ğyl. dok. diss. - Almaty, 1999. - $284 b$.

5 Qasym B.Q. Qazaq tılındegı zattyñ kürdelı ataularynyñ teorialyq negızderı: Filol. ğyl. dok. diss. Almaty, 2002. - $313 \mathrm{~b}$.

6 Zemskaia E.A. Sovremennyi ruski iazyk: Slovoobrazovanie. - M: Prosveşenie,1983. - 304s.

7 Uluhanov I.S. O stepenäh slovoobrazovatelnoi motivirovannosti slov //V̈̈,.1992, №5. - s. 107-110.

\title{
МРНТИ: 16.21.55
}

\author{
Исмаилова Ф.К. ${ }^{l}$ \\ ${ }^{1}$ Абай атындавы ҚазҰПУ, \\ Алматы, Қазақстан
}

\section{ДИПЛОМАТИЯЛЫҚ ДИСКУРСТЫҢ КОММУНИКАТИВТІ-ПРАГМАТИКАЛЫҚ ЕРЕКШЕЛІКТЕРІ}

\section{Аң̧датпа}

Мақала дипломатиялық дискурсты институционалдық дискурстың бір тармағы ретінде қарастыра отырып, оның коммуникативті және прагматикалық ерекшеліктерін анықтауға арналады. Дипломатиялық дискурс тілдік, когнитивті және коммуникативтік аспектілердің бірлігі ретінде қарастырылады. Дипломатиялық дискурстың тағы бір факторы - бұл барлық қарым-қатынастың сәттілігін анықтайтын дипломаттың лингвистикалық тұлғасы. Дипломатиялық дискурстың ажырамас компоненттері ретінде сыпайылық пен манипуляция категориялары атап өтіледі. Мақалада дипломатиялық дискурста қолданылатын тактика жан-жақты қарастырылған. Сондай-ақ, коммуникативті тактиканы таңдаудағы прагматикалық әдістің әсері анықталды: коммуникативті, интерактивті, перцептивті. Мақалада дипломатиялық дискурстың параметрлері институционалдық дискурс аясында зерттелді және оның негізгі жүйені құрайтын сипаттамалары ашылды. Соңғы жылдары ғалымдар дискурсты әртүрлі тәсілдер арқылы зерттеп жүргені белгілі. Мақалада дипломатиялық дискурсқа және оның лингвопрагматикалық категорияларына зерттеу жүргізу үшін басымдыққа алынатын алғышарттар (прагмалингвистика, дискурстық лингвистика, коммуникация теориясы) айқын көрсетілді. 